\title{
Report: Abstracts from the 2018 Caddo Conference in Idabel, Oklahoma
}

Amanda L. Regnier

Oklahoma Archeological Survey

Follow this and additional works at: https://scholarworks.sfasu.edu/ita

Part of the American Material Culture Commons, Archaeological Anthropology Commons, Environmental Studies Commons, Other American Studies Commons, Other Arts and Humanities Commons, Other History of Art, Architecture, and Archaeology Commons, and the United States History Commons

Tell us how this article helped you.

This Article is brought to you for free and open access by the Center for Regional Heritage Research at SFA ScholarWorks. It has been accepted for inclusion in Index of Texas Archaeology: Open Access Gray Literature from the Lone Star State by an authorized editor of SFA ScholarWorks. For more information, please contact cdsscholarworks@sfasu.edu. 


\section{Report: Abstracts from the 2018 Caddo Conference in Idabel, Oklahoma}

Creative Commons License

(c) (i) (8)

This work is licensed under a Creative Commons Attribution-NonCommercial 4.0 International License 


\title{
Report: \\ Abstracts from the 2018 Caddo Conference in Idabel, Oklahoma
}

\author{
Amanda L. Regnier \\ Oklahoma Archeological Survey
}

The 2018 Caddo Conference was held March 8-10, 2018 at the Museum of the Red River in Idabel, Oklahoma. Fifty attendees registered for the conference. The conference began with a reception at the museum on Thursday evening. On Friday, the program included eight papers and presentations covering archaeological work in Texas and Oklahoma and a longer presentation on the rebuilding of the Caddo house at Caddo Mounds State Park in Texas. A poster session was also held on Friday afternoon. Conference attendees were given a tour of the collections housed at the museum, which include a large collection of Caddo vessels and objects from all over the world. Friday ended with dances by the Metro Oklahoma City (OKC) Caddo Culture Club, beginning with the Turkey Dance and a delicious barbecue dinner held at the museum. On Saturday, the eight presentations covered sites in Arkansas and Oklahoma, Spiro iconography, and included a presentation on the Spiro exhibit forthcoming at the Cowboy and Western Heritage Museum in Oklahoma City. Just before breaking for lunch on Saturday, Caddo Culture Club and Metro OKC Caddo Culture Club members led a song using the large drum on exhibit in the museum.

\section{ABSTRACTS for the 70th CADDO CONFERENCE}

\section{Paper Abstracts}

\section{Analysis of the Kelly Creek Site Biface Cache, Garland County, Arkansas \\ Robert L. Brooks \\ Oklahoma Archeological Survey, emeritus}

A cache of 26 bifaces was removed from the Kelly Creek site in southwest Arkansas, probably during the 1990s. Regrettably, the absence of documentation at the time of removal has limited some elements of this presentation. My paper follows the history of the cache as it moved through the collecting community before being donated to the Museum of the Red River. An overview of the Kelly Creek site further demonstrates the need for good documentation when caches (or any artifacts) are found in locations with multiple components. Analysis of the 26 bifaces presents basic observations and some comments on characteristics of the cache. A few speculations are made concerning the functional role of the bifaces in their cultural context.

\section{Uncovering a Pit at Caddo Hills (3MN22) Chelsea Cinotto \\ Arkansas Archeological Survey}

In 1973, after commercial bulldozing uncovered archeological features, the Arkansas Archeological Survey's Henderson Research station, led by Ann Early, conducted a salvage excavation at the Caddo Hills site in the Upper Caddo River drainage in Arkansas. Feature 1 was a rectangular area that had been recently disturbed. Feature 2, the focus of the excavation, was a 3 by 3 meter pit that had been relatively undisturbed. Excavation of the pit revealed a variety of Native American artifacts: chipped and ground stone, ceramics, animal bone, and burned seeds and nuts. The artifacts have now been analyzed to investigate when and why the pit was created and filled. These results and interpretations are discussed here. The pit contained artifacts from several different time periods, with the most recent dating to the late Caddo period. The deposition of artifacts suggests the Caddoan material was originally discarded elsewhere and then later brought in to quickly fill the pit. In the future, this analysis can be used for researching connections to the nearby Standridge site and comparing to other Caddo sites in the Ouachita Mountains. 
Analyzing the Features at the Holman Springs Site (3SV29), a Caddo Saltworks in the Little River Basin Carl G. Drexler

Arkansas Archeological Survey

The Arkansas Archeological Survey and Arkansas Archeological Society excavated at the Holman Springs site (3SV29), in Sevier County, between 1984 and 1986. Those projects are now being processed and reported. As part of that effort, the Survey created a digital map of the features identified during those excavations and this paper examines patterns in the arrangement of those features. Comparisons with other Caddo saltworks are made. It also identifies next steps in the process of analyzing the vast trove of data on hand from this site.

Legacy Collection Update: The Johnny Ford Site, 3LA5, and its Cremation Cemetery

Ann M. Early

Arkansas Archeological Survey

One of the first volunteer excavations undertaken by the Arkansas Archeological Survey was a five day project held in 1970 at the Johnny Ford Site, an open site in the Red River alluvial valley in far southwest Arkansas. Landowner Herschel Kitchens and Dr. Frank Schambach were interested in the abundant Early Woodland bone tempered pottery and dart points on the surface and hoped to learn more about what Schambach called the Field Bayou Phase of initial pottery making culture in the region. They found artifacts confined primarily to the plowzone and a scatter of features that included human cremations. Although referred to in subsequent papers about Fourche Maline culture, the materials were not analyzed or published. In 1993, graduate student Jack Stewart completed a manuscript draft that was not brought to publication. In line with the Survey's 50th Anniversary initiative to inventory all legacy projects and bring collections and records up to archival standards, I am conducting a new inventory and analysis with an eye to eventual publication. Since Stewart's work, we now have a forensic study of what turn out to be 26 cremations, and new radiocarbon dates.
The Neosho Problem: Debates, Issues, and Proposed Resolutions

Paige Ford

University of Oklahoma

The Neosho phase (AD 1400-1650) in northeastern Oklahoma, northwestern Arkansas, southwestern Missouri, and southeastern Kansas represents Late Pre-Contact peoples engaged in widespread trade from the Plains to the southeastern United States. The phase has perplexed researchers since its definition, though debates predominately concern one of two main questions concerning the identity of Neosho peoples: emergence and cultural affiliation. Most research to date has focused simply on the question of emergence. Early in these debates, Orr (1946) suggested that Neosho peoples represented one or more plains-oriented groups that had migrated into the area, while Purrington (1971) later argued that Neosho represented a dissolution of the Arkansas River Valley Caddoan-Mississippian system. Numerous issues have inhibited progress in defending either of these models, including a dependence upon research methods relying upon descriptive cultural trait lists, a reluctance to contextualize and emplace Neosho peoples within the region at large, and even the initial definition of the phase and core culture area. This paper represents the beginning stages of my dissertation research and will focus on discussion of the Neosho phase, previous research, issues and debates, and proposed resolutions to the question of Neosho emergence.

\section{The Discovery and Recovery of a 14th Century Dugout Canoe on the Red River}

Jeffrey S. Girard

Northwestern State University

Early in June 2017, a remarkable prehistoric dugout canoe was discovered on the banks of the Red River north of Shreveport, Louisiana. At $10.2 \mathrm{~m}$ (about $34 \mathrm{ft}$ ) in length, it is the largest yet discovered in Louisiana, and one of the largest in the Southeastern United States. A radiocarbon date indicates that the canoe was constructed in the 14th century. This presentation summarizes the challenges that confronted researchers and local volunteers for extracting the canoe from the 
riverbank and transporting it to Texas A\&M university for conservation; and provides information about nearby Caddo village and ceremonial sites whose past inhabitants might have made and used the boat.

\section{Excavations at the Honey Locus Site (41SM476)}

Josh Haefner, Hicks \& Company Environmental Consultants

Victor Galan, Deep East Texas Archaeological

Consultants

Throughout 2017, Hicks \& Company Environmental Consultants conducted data recovery excavations at the Honey Locus Site (41SM476) located near Lindale, Texas. While diagnostic artifacts suggest at least minimal site-use from the Middle Archaic, data indicates intensive Woodland to Caddo Period occupations. Initial investigations included shovel testing, backhoe trenching, $1 \times 1 \mathrm{~m}$ test units, and a magnetometer survey to guide subsequent block excavations and systematic mechanical trenching. The investigations documented several large burned rock features, small pit and post features, along with 13 Caddo burials. Artifacts include a variety of dart points, arrow points, debitage and pottery sherds. While detailed analysis of the artifacts and special samples are ongoing, this presentation describes the excavation methodology, features, and available data.

\section{The Symbolic Use of Color and Directionality in the Spiroan Arkansas River Drainage}

Scott W. Hammerstedt and Sheila Bobalik Savage Oklahoma Archeological Survey

Color and directional symbolism were important components of the ritual beliefs and practices of Southeastern and Plains societies. This paper examines the use of color and directionality at a number of Spiroan mound sites in the Arkansas Valley in eastern Oklahoma. Artifacts, mound construction, and structure orientation will be discussed. We then draw on ethnohistoric descriptions to illustrate the role of color and directionality in Spiroan ritual life.

\section{A Provenance and Stylistic Study of Formative Caddo Vessels: Implications for Specialized Ritual Craft Production and Long-Distance Exchange}

Shawn P. Lambert

Utah Division of State History

Instrumental Neutron Activation Analysis is used to determine whether Formative Caddo finewares were made locally in the Arkansas River Basin or produced by their Gulf Coastal Plain neighbors to the south. The preliminary INAA results, in concert with a stylistic study indicating very few potters had the knowledge to produce them, show that Formative Caddo finewares were made in the southern Caddo region and exported north to Arkansas River Basin mound centers strictly for mortuary use. These findings suggest an extensive history of specialized ritual production and long-distance exchange between two diverse areas of the Caddo much earlier than expected.

\section{An Inventory of Reconstructed Ceramic Vessels from the Bowman Site (3LR50/3LR46) in Little River County, Arkansas \\ Duncan P. McKinnon, Katelyn Trammell, Ryan Nguyen, Anna Suarez \\ University of Central Arkansas}

A recent inventory of 36 heavily reconstructed vessels from the Bowman site (3LR50/3LR46) was completed by University of Central Arkansas (UCA) students as part of a directed study course on vessel documentation. The vessels are the result of several bags of broken vessels collected by Harold Spencer from Bowman in the 1960s and reconstructed by Arkansas Archeological Survey (ARAS) volunteers in the 1980s and 1990s. The inventory is part of a larger project to synthesize Bowman material in order to more fully understand site chronology and evaluate exchanges and social relationships with neighboring Red River community centers. While the vessels are heavily reconstructed and their intra-site provenience currently unknown, this initial documentation of vessels offers an example of the challenges inherent in old collections and a demonstration of how "excavation" of old collections can provide foundational knowledge in the development of broader research agendas. In this paper we provide 
a summary of the vessel inventory, including ceramic designs, possible types, and next steps in the much overdue evaluation of the Bowman site.

\section{Steaming Pots or Vessel Drums: Ethnographic and Ethnohistorical Evidence in Support of the Vessel Drum Interpretation of Two Shell Gorgets from Spiro}

Jim Rees

Arkansas Archeological Society

In two previously published articles (Rees 2010; Rees 2013), I argued that the vessels depicted on two shell gorgets from Spiro described by Phillips and Brown (1984: Pl. 126 and Pl. 127) as steaming pots were, in fact, ceramic vessel drums. The drum argument was largely supported by focusing on certain characteristics of the images themselves as well as comparisons with other examples of Mississippian and Mesoamerican iconography. The present paper will emphasize ethnographic and ethno-historical evidence for the use of ceramic vessel drums in the lower Mississippi valley and Trans-Mississippi Southeast in the 17th and 18th centuries. Of particular interest are the writings of Dumont de Montigny, a French army officer who not only provides a description and a drawing of a ceramic vessel drum used by the Natchez but also describes the contexts in which such drums were used.

\section{WPA-Excavated Harlan Phase Mound Sites in the Arkansas River Drainage}

Amanda Regnier, Scott Hammerstedt, and Sheila Savage Oklahoma Archeological Survey

Between 1934 and 1940, the University of Oklahoma sponsored excavations funded by federal depression relief programs at a number of mound sites in the Arkansas drainage of eastern Oklahoma. While the results of excavations at some sites, particularly Spiro, have been studied and written about extensively, others have been all but ignored. We have recently completed a manuscript documenting the excavations at seven of the mound sites. In this paper, we discuss three littleknown sites, Eufaula, Hughes, and Brackett, which were occupied during the Harlan phase (AD 1050-1240) and compare them to contemporaneous sites in the Arkansas drainage.

\author{
T-Bar and Wedge-Mouth versus Lightning and \\ Thunder \\ George Sabo III \\ Arkansas Archeological Survey
}

In their monumental Pre-Columbian Shell Engravings from the Craig Mound at Spiro, Oklahoma, Philip Phillips and James A. Brown consolidate a series of compositions (Plates 313 -323) within a "Paired Figures Confronting a Forked Pole" theme. Anthropomorphic figures on opposite sides of the forked pole exhibit "T-Bar" and "Wedge-Mouth" facial markings. This presentation reviews ongoing discussions concerning the story these images are intended to convey, with special attention devoted to the proposition that the figures might reflect an ancient precursor to "The Brothers who became Lightning and Thunder" narrative reproduced in George A. Dorsey's Traditions of the Caddo.

\section{A Partial Analysis of Ceramic Sherds Collected from the Bowman Site (3LR50/3LR46) in Little River County, Arkansas \\ Anna Suarez, Paula Long, Duncan P. McKinnon University of Central Arkansas}

A collection of unsorted ceramic sherds from the Bowman site (3LR46/3LR50) was recently analyzed by students at the University of Central Arkansas (UCA) as part of a directed study course in archaeological method. The collection is on loan from the Arkansas Archaeological Survey (ARAS) research station in Magnolia, Arkansas and is largely composed of artifacts obtained by local collectors Joe Shurtleff, James Chance, Harold Spencer, and Cleatious Thomas throughout the 1960s. Around 40 boxes define the collection and the analysis is only partially complete at this time. Nonetheless, the work conducted thus far contributes to broader goals of inventorying Bowman material and developing a better understanding of ceramic design styles, manufacturing forms, and vessel types present at the site. In this paper we introduce the Bowman site, summarize the history of excavations, and present preliminary results from the directed study. 


\section{Spiro and the Art of the Mississippian World}

\section{Eric Singleton}

National Cowboy and Western Heritage Museum

This presentation discusses the various components currently being developed by the National Cowboy \& Western Heritage Museum for the Spiro Mounds exhibition opening in February, 2021. The goal is to present, promote, and elicit discussion and feedback from tribal members and scholars regarding potential themes, layout, and presentation of objects.

\section{The Caddo Grass House Project}

Jeffrey M. Williams

Stephen F. Austin State University

A traditional Caddo grass house was built at Caddo Mounds State Historic Site near Alto, Texas during the summer of 2016. The fully functional grass house was constructed through a partnership with Caddo Nation elder Phil Cross and the Friends of Caddo Mounds. The Project included funding for a Caddo apprentice to work with Phil and the production of a documentary film that recorded the construction of the Caddo house from the identification and collection of raw materials through the final thatching. The new grass house provides Caddo Mounds State Historic Site with a tangible and visual foundation for interpreting Caddo lifestyle and culture. The Caddo house creates multiple opportunities for in-depth cultural exchange and offers supplemental historical reference of the Caddo people through the preservation and dissemination of Caddo knowledge about the skills required to gather the needed natural resources and the processes of design and construction of traditional Caddo grass houses.

\section{Poster Abstracts}

\section{Determination of the Origin of Caddo Artifacts Using SEM-EDS}

Lindsey Hazeslip, Anna Suarez-Davis, Robert Mauldin, Tom McCutchen, and Duncan P. McKinnon

University of Central Arkansas

The purpose of this project is to analyze a set of Caddo artifacts, currently on loan from the Arkansas Archeological Society, in order to determine whether they are naturally occurring or human-made. They were excavated from Mound 2 at the Bowman site in the 1960 's. It was hypothesized that the artifacts are a type of "iron concretion" that built up over time due to the flow of water through the sediment near the Red River. This project used a scanning electron microscope (SEM) with an energy dispersive $\mathrm{x}$-ray spectrometer to analyze the artifacts. The SEM helped determine which elements are present, and provided a rough estimation of the percentage of each element in the sample. The SEM is a non-destructive instrument, allowing for the same piece of sample to be used in further tests. The SEM identified sand ( $\mathrm{SiO} 2)$ particles embedded in an iron oxide matrix in the exposed interior of the sample, which supports the hypothesis that these artifacts are naturally occurring "iron concretions" and not human-made.

\section{Beginning the Ceramic Analysis of 3SV29, Holman Springs: A Caddo Salt-Processing Site in Sevier County, Arkansas}

Fiona Taylor, Arkansas Archeological Survey

The objective of this poster is to present data collected, research methods, and conclusions drawn from the ongoing ceramic analysis of the Holman Springs site (3SV29). This site was excavated during the 1985 and 1986 Arkansas Archeological Society’s Annual Training Programs, however, no systematic analysis or reporting of the artifacts was undertaken at the time. The Arkansas Archeological Survey's Southern Arkansas University Research Station in Magnolia, Arkansas currently houses 364 boxes of artifacts from archeological excavations at the Holman site, 269 of which are filled with pottery sherds. This translates to about $73 \%$ of all artifacts recovered from Holman Springs. By beginning the systematic analysis and inventory of the ceramic assemblage, I am fulfilling research obligations previously left uncompleted. Currently, I have examined and inventoried about $6.3 \%$ of the ceramic collection, which totals more than 8,600 sherds. The majority of sherds inventoried have been body sherds from large, utilitarian storage vessels. Although no diagnostic artifacts have been inventoried and no samples for radiocarbon dating have been sent at this time, I believe this is a Late Caddo site. Using an Access Database, I have been recording decoration, temper, course or fine wares, sherd forms (base, body, or rim), box location, and ceramic types when possible. This poster reflects data gathered from this analysis. 

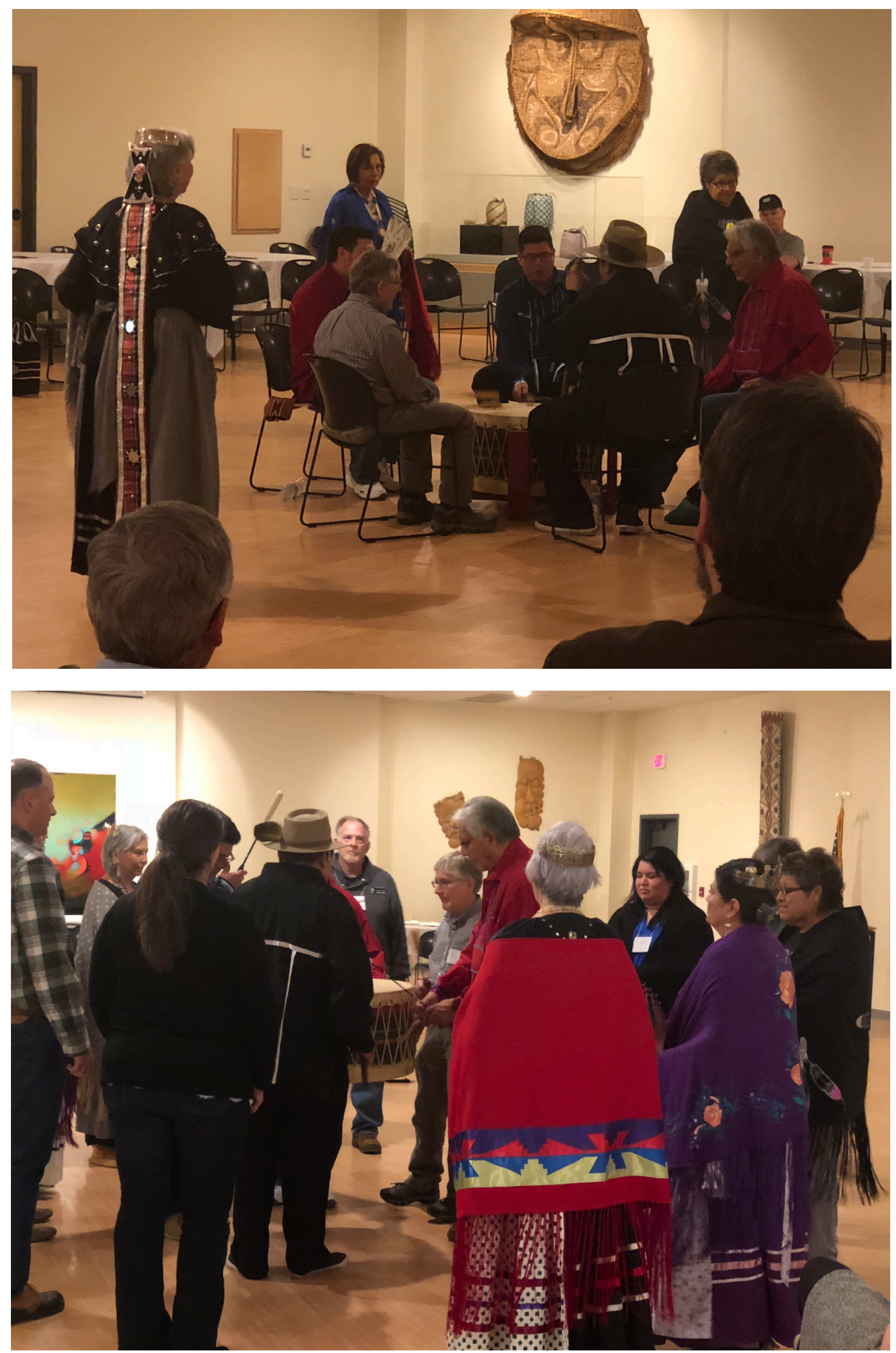